\title{
How to Write Academically as a Postgraduate Student from Non-English Speaking Background: A Study from Teachers' Perspective
}

\author{
Nick Zhiwei Bi \\ Faculty of Education and Social Work, University of Sydney \\ NSW 2006, Australia \\ Tel: 61-2-9351-2640Ｅ-mail: zhbi6097@uni.sydney.edu.au
}

Received: July 18, $2011 \quad$ Accepted: August 15, $2011 \quad$ doi:10.5539/ijel.v1n2p58

\begin{abstract}
This paper looks at issues on postgraduate students' academic writing by interviewing two academic staff at an English speaking university. From teachers' point of view, the study attempts to explain how to develop different kinds of skills to enable international students from EFL (English as a Foreign Language) backgrounds to apply the academic writing theories to their written assessment. The paper also aims to build a connection between students and academic staff with regard to the requirements and expectations of writing academically at university.
\end{abstract}

Keywords: Academic writing, EFL students, Teachers' perspective

\section{Introduction}

In English-speaking universities worldwide, the number of international students from non-English speaking backgrounds keeps rising rapidly. EFL students have played an important role in every aspect of university activities. However, because of different cultural and linguistic backgrounds, it is not uncommon to see those students coming to the university with different opinions and different construction of knowledge (Woodrow, 2006). As a result, these differences may become impediment for them to successfully meet the study requirements. Academic writing in particular, due to lack of training and knowledge on academic writing in English-speaking universities, many students from non-English speaking backgrounds do not understand the expectations and requirements from their course instructors with regard to their written assessment. In theory, academic writing has been discussed for many years, whereas, little empirical research has been conducted to discuss issues on academic writing from teachers' perspective. Since teachers are the direct audience of students' writing, it is important to know what they think are the most important issues that students need to pay particular attention to. This study, unlike many theoretical discussions on how to write academically, gathered information through interviews with academic staff at university. Based on analysing their opinions and looking at students' writings, the study summarises different types of issues on academic writing into five aspects, namely audience, purpose, discourse community expectations, structure of text and language features. This paper discusses the five topics in relation to the theory and practice, in terms of the assessment task the study is reporting on. It is not a conclusive study, but aims to gather a variety of solutions which can contribute to successful academic writing, because after all academic writing involves quite a number of issues to discuss and the good writers have their own choice of gaining the access to the academic discourse community.

\section{Method}

\subsection{Students' assessment}

The assessment is selected from one unit (Additional Language Learning) from Master of Applied Linguistics program in linguistics department at the University of Sydney, which consists of three continuous data analysis tasks during the semester. There are two lecturers (Lecturer A and Lecturer B) teaching this unit and each is in charge of half of the unit. This course is based on overview of the various theories of second language learning and questioning the traditionally influential psycholinguistics theories in this area. The whole course places a stronger emphasis on more recent sociocultural perspectives, systemic functional linguistics (SFL) and critical theories of additional language learning. This continuous assessment, therefore, examines students' knowledge 
and understanding of these three theoretical frameworks of language learner analysis. 10 essays written by students were selected by two lecturers to illustrate issues and problems in academic writing.

\subsection{Interviews}

The interview data was gathered from a 2-hour interview with two university lecturers. Semi-structured interviews were conducted in this study as this method compromises two extremes in both structured and unstructured interviews. Though the semi-structured interviews have pre-prepared guiding questions, the design is still open-ended and the researcher tried to encourage two lecturers to explain more on the questions. In this study, the way that the interviewer used to collect information was more flexible because though each staff was asked the same question, the wording and the order were not the same.

\section{Findings and discussion}

The findings of this study are summarised into five different aspects. The results are analysed by combining theories and practice to cover all the information gathered from interviews with two academic staff and students' essays.

\subsection{Audience of the assessment}

The first question two lecturers answered was in relation to audience of students' writing. Lecturer A and lecturer B both agreed

'The primary audience of this assessment is themselves, namely lecturers.' (Lecturer A \& lecturer B, interview 2010)

Both of them have $\mathrm{PhD}$ in applied linguistics and have been working at university for a couple of years. Consequently, they are not only experts on the unit itself, but are also quite familiar with different types of issues related to academic writing. They pointed out that it is greatly important for students to think about the audience of their assignments at the very beginning. Swales and Feak (1994) also indicate that before starting to write, students should consider their audience. They need to have the knowledge of what the audience's expectations and assumed knowledge about the assignment topics, because this will affect the contents of students' writing. In other words, students will be better to make assumptions about what the lecturers know, they do not know, and what they want to know before writing, and this knowledge will help them make decisions about all aspects of their writing (Leki, 1995). Brick (2006) suggests that when students write for an academic audience, they must use an impersonal and objective tone. However, it is very confusing for many students since the academic assessment usually requires students to express their own opinion about the ideas and issues. For instance, this assessment asks students to express their opinion on analyzing learner's language (e.g., What grammatical metaphor do you think the learner is using here?). This type of questions actually requires writers to have an academic argument rather than an everyday opinion. Therefore, writers must provide those arguments with appropriate evidence. In this assignment, the analyses are very subjective, because the writers will get different conclusions with different arguments. Hence, the lecturers emphasized in class that they are looking for the reasonable argument provided by the students rather than yes or no answers. Brick (2006) points out that the audiences of the academic writing are trying to see whether the students provide a clear position; develop a logical argument with reasons; understand the major concepts in relation to the topic; whether students can evaluate other writers' ideas and why; identify the voices of your own and others properly. Thus, writers must consider those issues before writing up the assessment so that they can meet the requirements that the audiences are expecting.

Furthermore, researchers (Jolliffe \& Brier, 1988; Lillis, 2001)) claim that relying on readers to keep the solidarity of the academic discourse is not necessary, however, the writers must demonstrate their understanding of knowledge of shared knowledge and stick to the community's conventions. Burgess (2002) points out that the writer's purpose is to demonstrate to the audience an ability of understanding and being aware of the particular academic area rather than merely repeat the research or concept from other scholars. As academic writings' target readers are primarily the instructors of the course, students need to write in a different manner compared to writing to someone who is totally unfamiliar with the study field.

\subsection{Purpose of the assessment}

With respect to the purpose of this assessment, lecturer A said

'Students usually lack of awareness of the purpose of their assignments, many of them would say that assignment will allow the lecturers or tutors to check their understanding of what is being taught. However, this is not completely true.' (Lecturer A, interview 2010) 
He emphasized that understanding the purpose of the assignment is crucial for students to complete a successful task and students' ability to use knowledge in a debate with others is also a key factor for an excellent writing.

As for this assignment, the main aim is to teach students to understand the sociocultural perspectives of second language learning. The assignment not only examines the students' understanding of the knowledge, but also how they can use the knowledge to solve problems as well as reflect on their own learning and teaching. Lecturer B emphasized that

'We are looking for evidence that students evaluate other scholars' voices, express their own voice and relate them with academic evidence properly.'(Lecturer B, interview 2010)

Once again, other researchers have also devoted close attention to help students to understand the purpose of their assessment at the very beginning. Brick (2006) indicates that the purpose of an assignment is to 'present a clear position and defend it' (p.108). Lecturer B explains that

'To defend it, students need to adopt other scholars' ideas to support their positions. The supporting evidence to explain why they are appropriate or not for their discussion.' (Lecturer B, interview 2010)

However, as a student, the purpose of what they write is quite different from the text they read (Brick, 2006). Therefore, the academic expectation for students will not be as high as experienced writers. Nonetheless, the lecturers still expect students to develop the position of their own and use these positions to link argument together. Lecturer B suggested that

'Writer's own voice is important in academic writing, because it introduces and presents each argument, and it is the dominant voice and the voice which controls the argument.' (Lecturer B, interview, 2010)

Therefore, for student writers, they are highly expected to contribute their own ideas which show their good understanding and interpretations of other scholars' ideas.

\subsection{Discourse community expectations}

Borg (2003) claims that writers do not use their writings to communicate with the general public, whereas they exchange ideas with individuals or groups of individuals. Lecturer A and lecturer B agreed that 'Applied Linguistics' is the name of their discourse community. Accordingly, students in linguistics department are gathered into this group. Swale (1990) identifies discourse community as groups that have goals or purposes, and use communication to achieve these goals. However, many researchers (Canagarajah, 2002; Hyland \& Hamp-Lyon, 2002; Borg, 2003; Paltridge, 2004; Woodward-kron, 2004) argue that as the changing of university and student population, the notion that discourse communities as static, autonomous and predictable should be questioned. Hyland and Hamp-Lyon (2002) found that the researchers and practitioners failed to conceptualize participants, texts and knowledge building practices which contribute to a discourse community. Woordward-Kron (2004) points out that the teachers are taking risk to generalize the knowledge to students about the academic writing without conceptualization. Therefore, students' writing usually cannot fulfil the standard of specific disciplinary context. Two lecturers also said

'Students especially from Asian backgrounds, most of them do not prepare for diversity of written genres they were required to engage in.' (Lecturer A \& Lecturer B, interview 2010)

It raises the question that whether the common discourse community expectation is applicable for students who already have other community features (Canagarajah, 2002).

In terms of above discussion, it may be very 'fuzzy' whether student writers should follow the general rules or not. However, the current prevailing view still suggests that if a writer would like to become acceptable, he or she has to enter into a discourse community. Johns (1997) suggests that 'text and language, genres and lexis, in the discourse community, enable members throughout the world to maintain their goals, regulate their membership, and communicate effectively with one another' (p.51). Therefore, students have to develop the 'insider' knowledge in order to be permitted relatively easy access to the activities of the community.

Firstly, students should have an assumed knowledge about what represents a good writing so that they can gradually become familiar with the shared discourse of the community. Generally, a good academic writing is the process of many considerations: audience, purpose, flow, presentation and positioning of the assessment (Swales \& Feak, 1994). Apart from these aspects, one of the notions, a university education is to have 'generic competence' might be a preferable way for student writers. Paltridge (2004) states that academic genres 'take us beyond the language and form of the text to a consideration of ways in which academic texts are embedded in 
the communicative activities of the academic community' (p.91). In other words, genre which is beyond the text might enable novice writers to gain the access into community more successfully. Paltridge (2002) claims that the responsibility of genre is to help students to have ability to 'negotiate the varied and changing literacies they will meet in their academic and future life' (p.24). As a result, in this no longer fixed, homogenous discourse community, to write a good essay or report may not only focus on textual level. On the contrary, students may seek to consider the cultural and social context of text they are writing to achieve a better outcome in their academic writing (Paltridge, 2002).

\subsection{Structure of text}

The assessment requires traditional essay format approach to write. Lecturer A said

'I have marked the assignment analytically, that is, I put scores on different components related to the stage of the assignment as well as language and referencing style' (Lecturer $\mathrm{A}$, interview 2010).

Crème and Lea (1997) summarize that traditional essay format will first have 'an introduction, which sets the scene; a main body, in which you outline and develop your argument; a conclusion, in which you bring everything together' (p.35). Crème and Lea claims that though most students know this procedure, in reality, many of them are still struggling with what the final write-up should be.

In order to achieve a better outcome in structuring the text, understanding the function of each part in the writing is very important. Writers need to know a number of functions that one paper's introduction, body and conclusion have so that they can write up a reasonably satisfactory structure. Taking introduction for an example, as essay or report writing is a deductive process (Brick, 2006), writers need to express their position that they will argue in the body at the beginning. Here, if they write a very clear introduction with general topic, important issues, positions to argue, the readers will easily find the positions and the arguments in the body. Betts et al (2005) point out that in academic writing, writers should convince the readers that the argument is appropriate. In order to do that, writers need to 'state the argument early on so that the audience can tell whether the evidence provided is convincing' (p.103). When structuring the text here, writers should also devote efforts in body and conclusion and the main focus should still focus on the argument. In the interview, lecturer B also pointed out

'If the writer can plan one argument, express it fairly at the beginning, provide evidence in the middle, and summarise it at the end, the writer will be on the right track to be a good writer' (Lecturer B, interview 2010).

Additionally, Betts et al (2005) also state that essays or reports consist of paragraphs, and each is just like a mini essay. The audience needs to check the more detailed structures after obtaining the general feature of the writer's writing. They suggest that each paragraph should also contain topic sentence, elaborations and a concluding sentence. Accordingly, doing this will provide the audience the added value of student's writing quality.

\subsection{Language features}

Swale and Feak (2000) point out that the formal academic-style writing shares many similar features: 'the avoidance of the first and second person pronouns $I$ and you, of contractions such as isn't, and of colloquial expression such as pretty nice' (p. 17). They also suggest that in the academic writing style, the passive voice and vocabulary from Latin, Creek or French origin are preferable to used. Two lecturers also expressed similar expectations when being asked questions regarding academic language use. Lecturer B said

'We expect students to use formal language and avoid colloquial ones. Applying interpersonal metaphor in their writings and avoid using explicit subject, such as I believe, I think, I agree, etc' (Lecturer B, interview 2010).

It is obvious that academics and teachers are concerned significantly about the language use in academic writing. At a textual level, in order to write an objective, impersonal language in the assignment, students should avoid using some judgmental or emotive language. Halliday (1994) defines this type of language use as grammatical metaphor (e.g., experiential, logical, interpersonal metaphor). According to Thompson (1996), experiential metaphor such as nominalisation can be a very powerful weapon in expressing writer's or speaker's argument. In academic writing, one common technique is to objectify your opinion by nominalising it, which can make it much harder for readers to argue with that, as well as make the language more 'lexically dense' (Colombi. 2006; Paltridge, 2001), examples are 'the possibility of', 'the use of', etc. Additionally, in interpersonal metaphor (hedging), the expression of modality and evaluation is also used to achieve this goal, because expressions like ' $I$ think, I believe, I am sure, I am convinced etc,' are known as 'explicit subjective' (Martin et al, 1997). 
At the vocabulary level, students need to devote closer attention to academic and technical terms. Academic writing requires more formal vocabulary than in the casual conversation. Hence, the use of academic vocabulary will enhance the formality of a text (Nation, 2001). Technical vocabulary contains the words that are very related and close to the topic and subject areas. Here will take two short extracts from students' writing as examples.

\section{Extract 1. Example of academic and technical vocabulary in academic writing from students' essay}

'Experiential metaphor is also called nominalisation, which is inclined to transform verbs to nouns to reach incongruent meaning. In this essay, there are various examples of experiential metaphor'.

In this extract, the words in bold are technical words in applied linguistics and words in italic are some academic words. 'Experiential metaphor' and 'nominalisation' are vocabulary in systemic functional linguistics, which are common in this topic area but not so common elsewhere, however, as soon as learners or researchers see them they will know what topics are being discussed. On the other hand, academic words or expressions such as 'be inclined to', 'transform', have the function of enhancing the formality and learnedness of the text.

In addition, hedged language is also a kind of academic language feature. Hyland (1994) suggests hedged proposition is very common in academic writing. It usually allows writers to be uncertain about factuality of their statements. Therefore, academic writing usually involves epistemic modality, which is also defined as interpersonal metaphor by functional linguistics talked above.

\section{Extract 2. Example of hedging in academic writing from students' essay}

'The reason why Franz did not use explicit expression to indicate his identity is that he might feel quite ideologically contested when facing two different identities (culturally as a South African, but nationally as a New Zealander) existing'.

Auxiliary verb 'might' used in the above example is to express a hedged proposition. This statement reveals judgement but with acceptable reasoning. Therefore, it fulfils principle of the impersonal style in academic writing, which also qualifies writers' claims with an indication that they may not be true or apply in all cases, or be believed by all.

\section{Conclusion}

This study provides an overview of the characteristics of academic writing. From the above analyses, it can be learnt that, in order to achieve a better outcome in academic writing, student writers need first to be aware of the audience because the knowledge of the audience will have an impact upon the content of their writing; second, writers need to understand the purpose of their assessment and provide a position and then defend it; third, writers should also try to enter an discourse community to enable themselves to communicate with other members; next, if academic writers have a clear structure of the writing, they will be on the way to become a successful writer; finally, to learn how to use different vocabulary and apply them properly will provide writer's language an added value. Due to the scale of the study, it cannot cover all the issues related to academic writing. However, the discussion might create a connection between students and teachers regarding the standards and expectations of academic writing. In addition, the study may also enrich student writers' understanding of academic writing and reflect on their writing on the basis of theory and practice.

\section{References}

Betts, K., Farquharson, K. \& Seitz, A. (2005). Writing essays and research reports in the social science. ( $3^{\text {rd }}$ ed). Melbourne: Thomson.

Borg, E. (2003). Discourse community. ELT journal, 57(4), 398-400. doi:10.1093/elt/57.4.398, http://dx.doi.org/10.1093/elt/57.4.398

Brick, J. (2006). Academic Culture: A Student's Guide to Studying at University. Sydney: Macquarie University.

Burgess, S. (2002). Packed houses and intimate gatherings; audience and rhetorical structure. In J. flowerdew (Eds.), Academic discourse (pp.196-215). Harlow, UK: Longman.

Canagarajah, S. (2002). Multilingual writers and the academic community. Journal of English for Academic Purposes, 1, 29-44. doi:10.1016/S1475-1585(02)00007-3, http://dx.doi.org/10.1016/S1475-1585(02)00007-3

Colombi, M. C. (2006). Grammatical metaphor: academic language development in Latino students in Spanish, In Byrnes, H. (Eds.). Advanced language learning the contribution of Halliday and Vygotsky (pp.147-163). New York: Continuum. 
Crème, P. \& Lea, M. R. (1997). Writing at university: a guide for students. ( $2^{\text {nd }}$ ed). Berkshire: Open University Press.

Halliday, M. A. K. (1994). An introduction to functional grammar. $\left(2^{\text {nd }}\right.$ ed). London: Edward.

Hyland, K. (1994). Hedging in academic writing and EAP textbooks. English for Specific Purposes, 13, 239-256.doi:10.1016/0889-4906(94)90004-3, http://dx.doi.org/10.1016/0889-4906(94)90004-3

Hyland, K. \& Hamp-Lyons, L. (2002). EAP: issues and directions in academic writing. Harlow, England: Longman.

Johns, A. M. (1997). Text, role and context: Development academic literacies. Cambridge: Cambridge University Press.

Jolliffe, D. A. \& Brier, E. M. (1988). Studying writers' knowledge in academic disciplines. In D. A. Jolliffe (Eds.). Advances in writing research. Vol. 2. Writing in academic disciplines (pp. 35- 80). Norwood, NJ: Ablex.

Leki, I. (1995). Academic writing: exploring processes and strategies. ( $2^{\text {nd }}$ ed.). London: Cambridge University Press.

Lillis, T. M. (2001). Study writing access, regulation, desire. London: Routledge.

Martin, J., Matthiessen, C.M. \& Painter, C. (1997). Working with functional grammar. London: Arnold.

Nation, I.S. P. (2001). Learning vocabulary in another language. Cambridge: Cambridge Applied Linguistics.

Paltridge, B. (2001). Genre and the language learning classroom. Ann Arbor: University of Michigan Press.

Paltridge, B. (2002). Academic literacies and changing university communities. Revista Canaria De Estudios Ingleses, 44, 15-28.

Paltridge, B. (2004). Academic writing. Language Teaching, 37, 87-105. doi:10.1017/S0261444804002216, http://dx.doi.org/10.1017/S0261444804002216

Swales, J. M. (1990). Genre Analysis. Cambridge: Cambridge University Press.

Swales, J. M. \& Feak, C. B. (1994). Academic writing for graduate students: a course for nonnative speaker of English. Ann Arbor: University of Michigan Press.

Swales, J. M. \& Feak, C. B. (2000). English in today's research world: A writing guide. Ann Arbor: University of Michigan Press.

Thompson, G. (1996). Introducing functional grammar. London: Arnold.

Woodrow, L. (2006). English in academic settings: A postgraduate course for students from non-English speaking backgrounds. In M. A. Snow \& L. Kamhi-Stein (Eds.), Developing a new course for adult learners (pp. 197-218), Sydney: TESOL.

Woodward-Kron, R. (2004). 'Discourse communities' and 'writing apprenticeship': An investigation of these concepts in undergraduate education students' writing. Journal of English for Academic Purposes, 3, 139-161. doi:10.1016/j.jeap.2003.09.001, http://dx.doi.org/10.1016/j.jeap.2003.09.001 